\title{
Etlingera elatior Extract promotes cell death in B16 melanoma cells via down-regulation of ERK and Akt signaling pathways
}

\author{
Aungkana Krajarng ${ }^{1}$, Malin Chulasiri ${ }^{2}$ and Ramida Watanapokasin ${ }^{3 *}$
}

\begin{abstract}
Background: Torch ginger (Etlingera elatior, EE) is a ginger plant that found in Southeast Asia. Previous study showed its flowers and leaves composed of several flavonoids with anti-cancer activity. This study aims to investigate the mechanism of EE extract on cell death induction in melanoma cells.

Methods: To carry out this study, the cytotoxic effect of EE extract was performed using MTT assay. Nuclear morphological change and loss of mitochondrial membrane potential were observed using Hoechst 33,342 and JC-1 staining. Flow cytometry using Annexin V/PI double staining assessed apoptosis, necrosis and viability. Caspase activity was detected by caspase activity kits. The expression of Bcl-2 family proteins, ERK and Akt signaling pathways were examined by Western blot analysis.

Results: The treatment of EE extract resulted in a dose- and time-dependent reduction in cell viability in B16 cells. It also induced nuclear condensation, phosphatidylserine exposure, and loss of mitochondrial membrane potential, which are markers of apoptosis. Furthermore, the expression of Bim was increased instead of Bax and Bcl-2. The results also showed caspase-independent activity and the down-regulation of ERK and Akt signaling pathway.

Conclusion: The results suggest that EE extract induced caspase-independent cell death via down-regulation of ERK and Akt pathways in B16 cells. This may be beneficial as a chemopreventive or chemotherapeutic agent in melanoma treatment.
\end{abstract}

Keywords: Etlingera elatior, B16 melanoma cells, Nuclear condensation, ERK, Akt

\section{Background}

Skin cancer is the most common cancer in the United States and Europe whereas is uncommon in Asia. The causes of skin cancer are from genetic mutation and also from environmental factors such as long time exposure to sunlight or UV light. Melanoma is less common cancer but is the most dangerous form of skin cancer because it can spread to other parts of the body. Melanoma is originated from the transformation of melanocyte, which produces the melanin pigment in the skin. Melanoma can occur anywhere on your body where there is melanin, even though it has not been exposed to sunlight [1]. However, the mechanism of melanoma is unknown. There are

\footnotetext{
* Correspondence: ramidawa@yahoo.com; ramidaw@g.swu.ac.th ${ }^{3}$ Department of Biochemistry, Faculty of Medicine, Srinakharinwirot University, Bangkok, Thailand

Full list of author information is available at the end of the article
}

different types of currently used treatment for patients depend on the stage of melanoma. Mostly, surgery or wide excision is the major treatment and also combined with chemotherapy, radiation therapy or immunotherapy [2]. At present, herbal medicine, which is an alternative medicine, is becoming a new way for cancer treatment. Many clinical studies have shown a spectrum of anticancer activities of herbal medicine and used as a combination to improve the efficacy and decrease side effects of chemotherapy and radiation therapy [3].

Torch ginger, Etlingera elatior (EE), is a plant in the ginger family (Zingiberaceae). It is native in Thailand, Indonesia, Malaysia, and widely cultivated in Southeast Asia. Its flowers and leaves have been used as spices for food flavoring and as ornamentals. Furthermore, it is also traditionally used for treating earache and cleaning wound. Postpartum women boiled leaves of EE mixed 
with other aromatic herbs for bathing to remove body odour [4]. In Australia and Hawaii, it is cultivated for cut flower production [5]. The phytochemical screening of methanol extract of EE flowers showed the presence of flavonoids, terpenoids, saponins, anthocyanin and tannin [6]. The GC-MS results of flower extract showed the main components were 1-dodecanol, dodecanol, and 17pentatriacontene [7]. It has been reported that leaves of EE composed of flavonoid including kaempferol and quercetin which showed high antioxidant activity and strongest tyrosinase inhibition activity [8]. Leave extract of EE also showed antibacterial activity against Grampositive bacteria of Bacillus cereus, Micrococcus luteus, and Staphylococcus aureus but no activity on Gramnegative bacteria of Escherichia coli, Pseudomonas aeruginosa, and Salmonella cholerasuis [9]. It also exhibited antifungal activity on Colletotrichum gloeosporioides [10]. Moreover, EE has been shown anticancer activity against cervical cancer HeLa cells [11], breast cancer CEM-SS and MCF-7 cells [12] but non-cytotoxic effect to normal human liver WRL-68 cells and African green monkey kidney Vero cells [13]. Our preliminary study [14] has reported that EE extract could inhibit cell proliferation and could induce apoptosis by cell morphological changes and nuclear condensation in human epidermoid carcinoma. However, the mechanism of $\mathrm{EE}$ extract in melanoma is not clear.

Here, we show that EE extract induce caspaseindependent cell death in mouse B16 melanoma cells via the inhibition of ERK1/2, p38 and Akt signaling pathway.

\section{Materials and methods}

\section{Plant extraction}

The flower extract of Etlingera elatior (EE) included 50\% hydroglycol was obtained from Dr. Malin Chulasiri. The fresh flowers of EE were collected from Pathumthani province, Thailand in September 2013 and were authenticated by a botanist. A voucher specimen (number SJ 002) was deposited at the Faculty of Medicine, Srinakharinwirot University, Bangkok, Thailand for future reference. The fresh flowers of $\mathrm{EE}$ were dried at $50^{\circ} \mathrm{C}$ and then ground. The powdered of EE was macerated in 50\% hydroglycol, which was prepared from proportion of water and glycols (propylene glycol or butylene glycol). After 3day maceration, the EE extract was filtered through Whatman filter paper No.1. The filtrate was kept refrigerated until use.

\section{Cell culture}

Mouse melanoma B16 cells and monkey kidney Vero cells were obtained from the American Type Culture Collection (ATCC, Manassas, VA). B16 and Vero cells were maintained as a monolayer in Dulbecco's modified Eagle's medium (DMEM, Gibco BRL, Grand Island, NY) supplemented with $10 \% \mathrm{FBS}, 100 \mathrm{U} / \mathrm{ml}$ penicillin and $100 \mu \mathrm{g} / \mathrm{ml}$ streptomycin (GE Healthcare, Utah, USA) at $37{ }^{\circ} \mathrm{C}$ in a humidified atmosphere of $5 \%$ carbon dioxide $\left(\mathrm{CO}_{2}\right)$. The medium was refreshed every 2-3 days. B16 and Vero cells were sub-cultured using $0.25 \%$ trypsinEDTA when the cells reached about $70 \%$ confluence.

\section{Cell viability assay}

Effect of EE extract on the cell viability was determined by using 3-(4,5- Dimethylthiazol-2-yl)-2,5diphenyl-2H-tetrazolium bromide (MTT) assay. B16 and Vero cells were seeded at a density $7 \times 10^{3}$ cells/well in a 96-well plate and allowed to grow for $24 \mathrm{~h}$. Cells were then treated with EE extract at various concentrations of $0,5,10,15,20$ and $25 \mu \mathrm{g} / \mathrm{ml}$ while the control group was treated with $50 \%$ hydroglycol for $24 \mathrm{~h}$. After incubation, $10 \mu \mathrm{l}$ of $0.5 \mathrm{mg} / \mathrm{ml} \mathrm{MTT} \mathrm{solu-}$ tion was added to each well and the plate was further incubated for $2 \mathrm{~h}$ at $37{ }^{\circ} \mathrm{C}$. The water-insoluble formazan crystal was dissolved in DMSO and the absorbance was measured at $570 \mathrm{~nm}$ using a microplate reader (Multiskan EX, Thermo electron corporation, Finland). Cell viability was expressed as percentage of viable cells of treated cells to control cells. Cells were treated in triplicates and the experiments were repeated three times. The IC50 value was calculated using the software GraphPad Prism 3.03 (GraphPad Software, Inc., San Diego, CA, USA).

\section{Detection of nuclear morphology by Hoechst 33,342 staining}

B16 cells were seeded at a density of $1.5 \times 104$ cells/well in a 48 -well plate and allowed to grow for $24 \mathrm{~h}$. The cells were then treated with $15 \mu \mathrm{g} / \mathrm{ml}$ of EE extract for 4,8 , 16 and $24 \mathrm{~h}$. Then cells were stained with $5 \mu \mathrm{g} / \mathrm{ml}$ of Hoechst 33,342 (Molecular Probes, Invitrogen, USA) for $30 \mathrm{~min}$. Stained cells were washed with PBS once and examined by using fluorescent microscope (Olympus, Tokyo, Japan).

\section{Detection of loss of mitochondrial membrane potential $\left(\Delta \Psi_{m}\right)$ by $\mathrm{JC}-1$ staining}

To determine $\Delta \Psi m$, the lipophilic cationic dye $5,5^{\prime}, 6,6^{\prime}-$ tetra- chloro-1,1',3,3'-tetraethylbenzimidazol-carbocyanine iodide (JC-1, Molecular Probes, Invitrogen, USA) was used. This dye concentrates as red aggregates in mitochondria that maintain high $\Delta \Psi m$. Upon excitation at $480 \mathrm{~nm}$, aggregates have a red emission light $(590 \mathrm{~nm})$ while monomers have a green emission light $(525 \mathrm{~nm})$. B16 cells were seeded at a density of $1.5 \times 104$ cells/well in a 48-well plate and allowed to grow for $24 \mathrm{~h}$. The cells were then treated with $15 \mu \mathrm{g} / \mathrm{ml}$ of EE extract for 4, 8, 16 and $24 \mathrm{~h}$. Then cells were stained with $10 \mu \mathrm{g} / \mathrm{ml}$ of $\mathrm{JC}-1$ for $15 \mathrm{~min}$. Stained cells were washed with PBS once and observed under fluorescence microscopy (Olympus, Tokyo, Japan). 


\section{Phosphatidylesreine exposure}

Phosphatidylserine exposure was detected using Dead Cell apoptosis Kit with Annexin V Alexa Fluor $^{\text {Tm }} 488$ \&/Propidium Iodide (PI) (Molecular Probes, Eugene, OR). B16 cell were seeded in 6-well plates and treated with $15 \mu \mathrm{g} / \mathrm{ml}$ of EE extract for $0,4,8,16$, and $14 \mathrm{~h}$. Cells were harvested and washed once with ice-cold PBS. Cell pellets were resuspended in $100 \mu \mathrm{l}$ of binding buffer, $5 \mu \mathrm{l}$ of Annexin V-FITC conjugate and $1 \mu \mathrm{l}$ of PI was added. The cells were incubated at room temperature for $15 \mathrm{~min}$ in the dark. After adding $400 \mu \mathrm{l}$ of binding buffer, the cells were analyzed using a FACScan flow cytometry (Becton Dickenson, San Jose, CA).

\section{Caspase activity}

Caspase activity was detected using the caspase- $\mathrm{Glo}^{\circ} 3 /$ 7,8 , and 9 assay kits (Promega, Madison, USA) according to the manufacturer's instructions. Briefly, B16 cells were seeded into black wall clear bottom 96-well plate at the density of $1 \times 104$ cells/well in triplicate wells and cultured overnight for attachment. Then cells were treated with $15 \mu \mathrm{g} / \mathrm{ml}$ of EE extract for 4, 8, 16 and $24 \mathrm{~h}$. After that $100 \mu \mathrm{l}$ of caspase-Glo ${ }^{\circ}$ reagents were added into each well. Samples were incubated for $30 \mathrm{~min}$ at room temperature and luminescence was measured using a microplate reader (Spark $20 \mathrm{M}$ Multimode microplate reader, Tecan, Switzerland).

\section{Western blot analysis}

B16 cells were seeded at $2 \times 105$ cells into a $35-\mathrm{mm}$ dish and treated with $15 \mu \mathrm{g} / \mathrm{mL}$ of EE extract for several time points. Then, cells were harvested and lysed with RIPA lysis buffer (50 mM Tris-HCl, pH 7.5, $5 \mathrm{mM}$ EDTA, $250 \mathrm{mM} \mathrm{NaCl}, 0.5 \%$ Triton X-100) containing $10 \mathrm{mM}$ PMSF and Complete Mini Protease Inhibitor Cocktail (Roche Diagnostics GmbH, Mannheim, Germany). Proteins were separated by 10\% SDS-PAGE and transferred onto polyvinylidene fluoride (PVDF) membranes (Pall Corporation, USA) for $1 \mathrm{~h}$ at $100 \mathrm{~V}$ with the use of a Mini Trans-Blot Cell ${ }^{\circ}$ (Bio-Rad). After blocking in 5\% bovine serum albumin (BSA), the membranes were incubated overnight at $4{ }^{\circ} \mathrm{C}$ with primary antibody (Cell Signaling Technology, Beverly, MA.) The membranes were washed in TBST $(10 \mathrm{mM}$ Tris, $\mathrm{pH} 7.5,150 \mathrm{mM} \mathrm{NaCl}$ and $0.1 \%$ Tween 20 ) and the appropriate secondary antibody conjugated with horseradish peroxidase (Cell Signaling Technology, Beverly, MA) was added for $1 \mathrm{~h}$ at room temperature. Immunoreactive protein bands were detected by chemiluminescence using enhanced chemiluminescence reagent (ECL, Millipore, Bedford, MA).
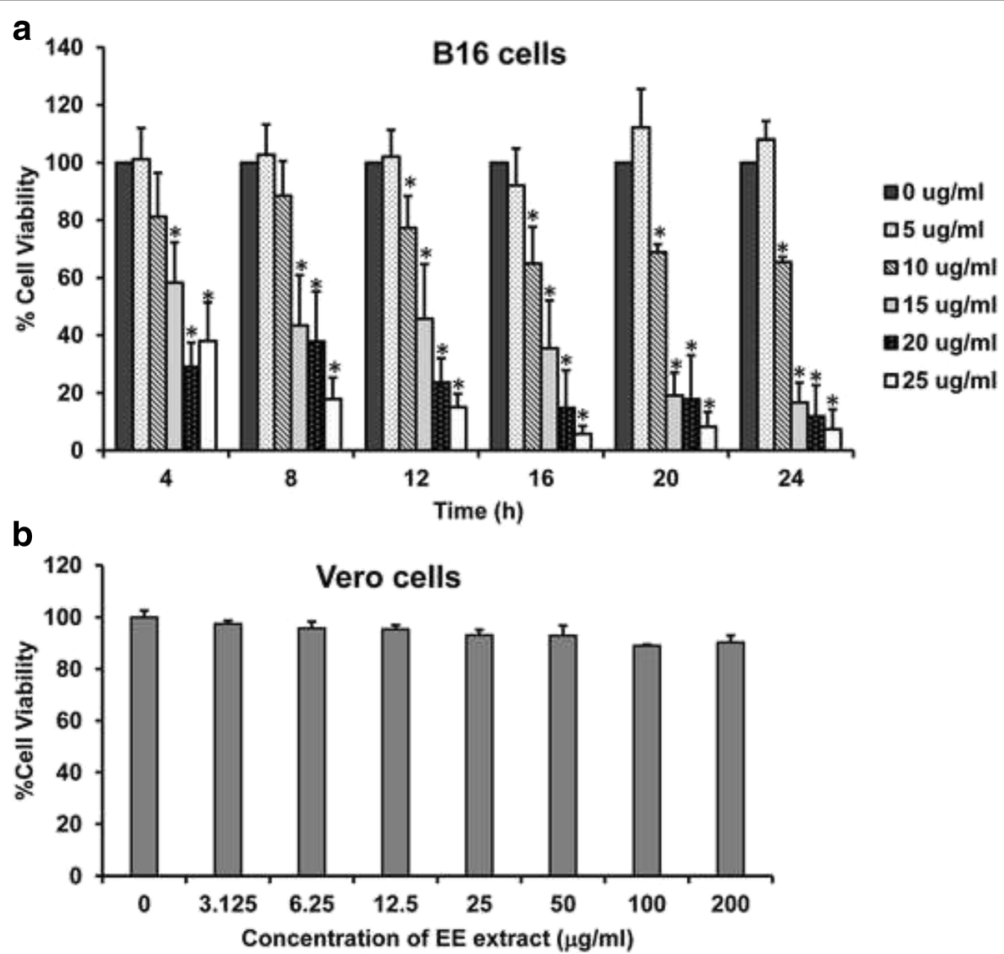

Fig. 1 EE extract inhibited cell viability in B16 cells. The cytotoxic effect of EE extract was performed using the MTT assay. (a) B16 and (b) Vero cells were treated with various concentrations of EE extract at different time points for $24 \mathrm{~h}$. Results are mean values \pm SD of three independent experiments $(n=3)$. ${ }^{*} p<0.05$ shows significant difference compared with control $(0 \mu \mathrm{g} / \mathrm{ml})$ 


\section{Statistic analysis}

Reported data represent mean \pm SD. All measurements were taken in triplicate from three independent experiments. Statistical significances between groups were analyzed using Student's $t$-test and accepted at $p<0.05$.

\section{Results}

\section{Cytotoxic effect of EE extract}

To investigate the cytotoxic effect of EE extract, the cancer cell line used in this study was mouse melanoma B16 cells whereas the normal cell line used was monkey kidney Vero cells. B16 and Vero cells were treated with various concentrations of EE extract for $24 \mathrm{~h}$. Cell viability was assessed using MTT assay. The result revealed that EE extract decreased B16 cell viability in a doseand time-dependent manner (Fig. 1a). In contrast, EE extract showed no cytotoxic activity against Vero cells (Fig. 1b). Accordingly, EE extract is only cytotoxic to melanoma cells and the $\mathrm{IC}_{50}$ of $\mathrm{EE}$ extract in $\mathrm{B} 16$ cells was about $15 \mu \mathrm{g} / \mathrm{ml}$ and this concentration was used in subsequent experiments.

\section{Effect of EE extract on nuclear morphological change}

To investigate nuclear morphology of B16 cells treated with EE extract at several time points, cells were stained with Hoechst 33,342 and examined under fluorescence microscope. The result showed that EE extract could induce nuclear condensation but could not observe nuclear fragmentation (Fig. 2).

\section{Effect of EE extract on mitochondrial transmembrane potential $\left(\Delta \psi_{m}\right)$}

Loss of mitochondrial membrane potential is one of characteristic in the induction of apoptosis. To measurement this event, B16 cells were stained with JC-1 dye. JC- 1 is the unique fluorescent cationic dye that forms aggregates and emits a red fluorescence peak at high mitochondrial membrane potential, while at low mitochondrial membrane potential JC-1 exists as monomer form and emits a green fluorescence peak. Figure 3 shows progressive loss of red JC-1 aggregate fluorescence of the EE extracttreated cells, appearance of green monomer fluorescence in the cytoplasm at $8 \mathrm{~h}$ and complete loss of red fluorescence presence of only green fluorescence at 16 and $24 \mathrm{~h}$. The changes from red to green fluorescence indicated a loss of mitochondrial membrane potential.

\section{Effect of EE extract on phosphatidylserine exposure}

Phosphatidylserine (PS) is a phospholipid which is a component of cell membrane. It indicates early apoptosis when PS is translocated from the inner to the outer leaflet of the cell membrane and display an "eat me" signal to prompt phagocytes to engulf the cell. Annexin VPI double-labeling and FACS analysis were used for the

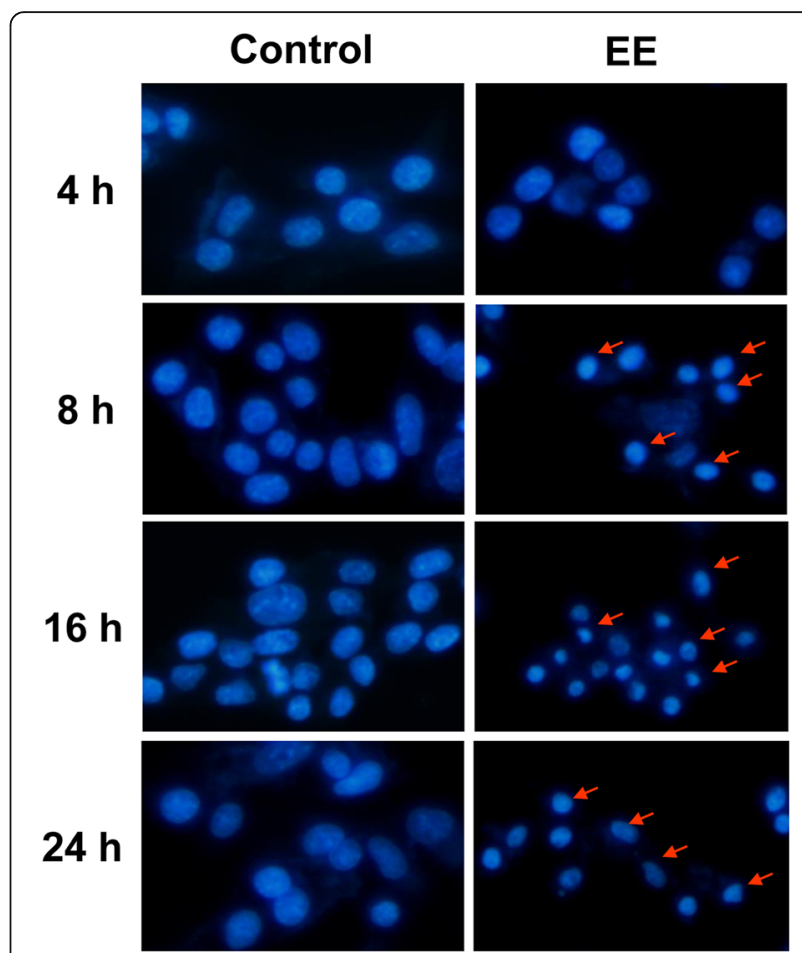

Fig. 2 EE extract induced nuclear condensation in B16 cells. B16 nontreated or control (left panel) and treated with $15 \mu \mathrm{g} / \mathrm{ml} \mathrm{EE} \mathrm{extract}$ (right panel) for $24 \mathrm{~h}$. Then cell were stained with Hoechst33342 and observed under a fluorescence microscope (20X magnification). The arrows show nuclear condensation of B16 treated cells

detection of PS externalization. As shown in Fig. 4, the four quadrants in each panel correspond, respectively, to necrotic cells (upper left, UL), late apoptotic cells (upper right, UR), viable cells (lower left, LL), and early apoptotic cells (lower right, LR). Results showed that EE extract induced early apoptotic cells slightly about $14 \%$ at 4 and $8 \mathrm{~h}$ whereas late apoptotic cells increased highly about $40 \%$ at 16 and $24 \mathrm{~h}$. These results suggest that EE extract induced phosphatidylserine exposure, a marker for apoptosis.

\section{Effect of EE extract on apoptosis induction}

The mechanisms of apoptosis can be divided into two major pathways; extrinsic or death receptor and intrinsic or mitochondrial pathways. Both pathways are activated by caspases. The Bcl-2 family of proteins, another mediator, has role as anti-apoptosis and pro-apoptosis. To observe whether EE extract induce apoptosis pathway, Bcl-2 family of proteins and caspase activity of caspase$3,-8$, and -9 were detected. The results revealed no significant change in Bax and Bcl-2 levels were observed upon EE extract treatment. However, Bim, a proapoptotic BH-3 only member of Bcl-2 family, was increased compared with control group (Fig. 5). 
$15 \mu \mathrm{g} / \mathrm{ml} \mathrm{EE}$
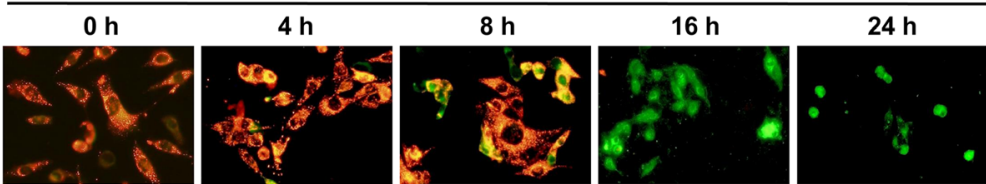

Fig. 3 EE extract induced loss of mitochondrial membrane potential $(\Delta \psi \mathrm{m})$. B16 cells were treated with $15 \mu \mathrm{g} / \mathrm{ml}$ EE extract for $24 \mathrm{~h}$. Then cell were stained with $\mathrm{JC}-1$ and observed at indicated time points under a fluorescence microscope (20X magnification)

Treatment of B16 cells with15 $\mu \mathrm{g} / \mathrm{ml}$ EE extract at various times resulted in lower activities of caspase-3/7, caspase- 8 and caspase- 9 compared with control group (Fig. 6). Therefore, our results may suggest that EE extract induce cell death in melanoma B16 cells via a caspase-independent mechanism.
Effect of EE extract on the expression of ERK and Akt signaling pathways

Mitogen-activated protein kinase or MAPK pathway is one of the drivers for melanoma. Members of the MAPK family are activated from extracellular signals via an ordered series of consecutive phosphorylation events,

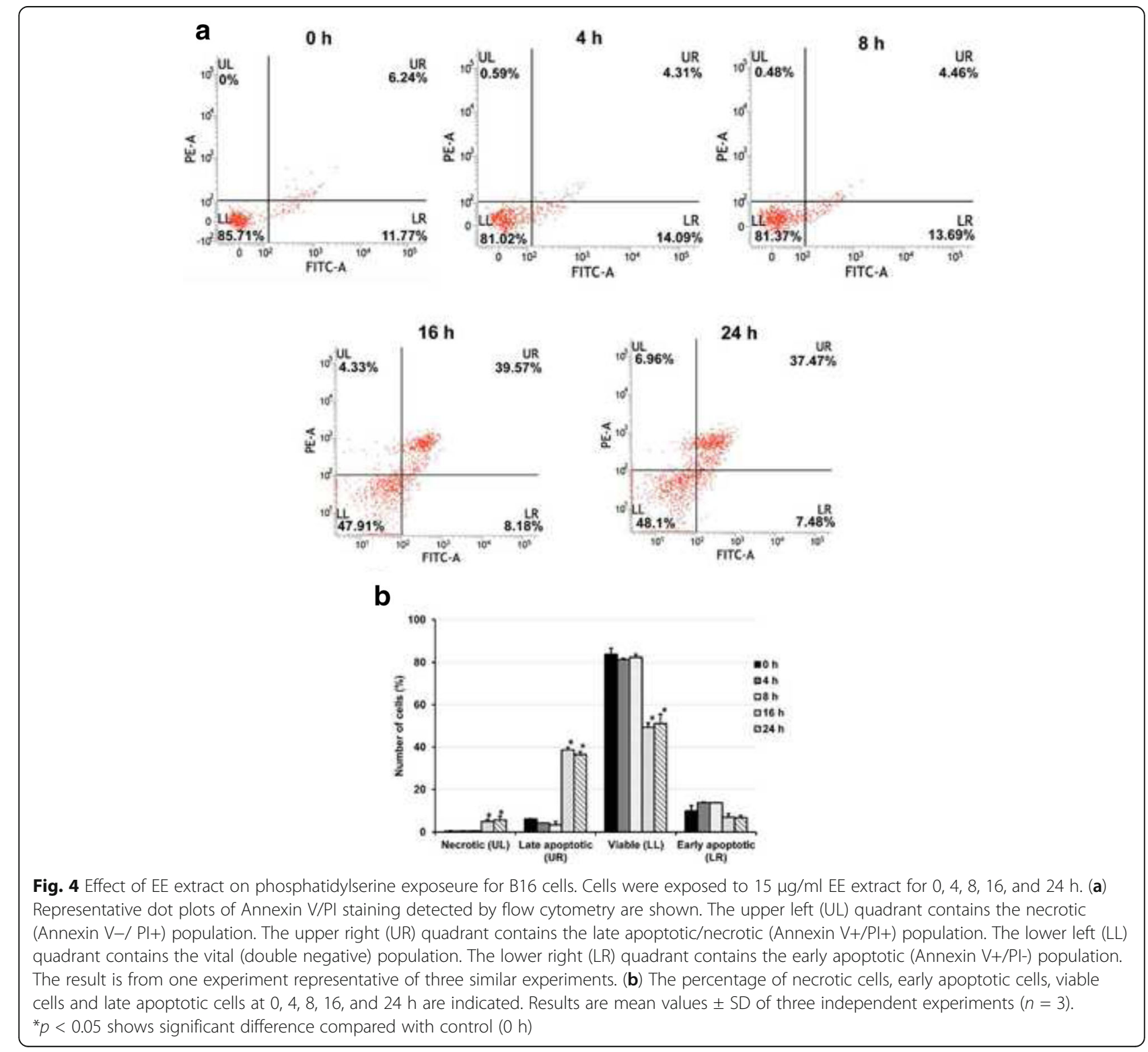




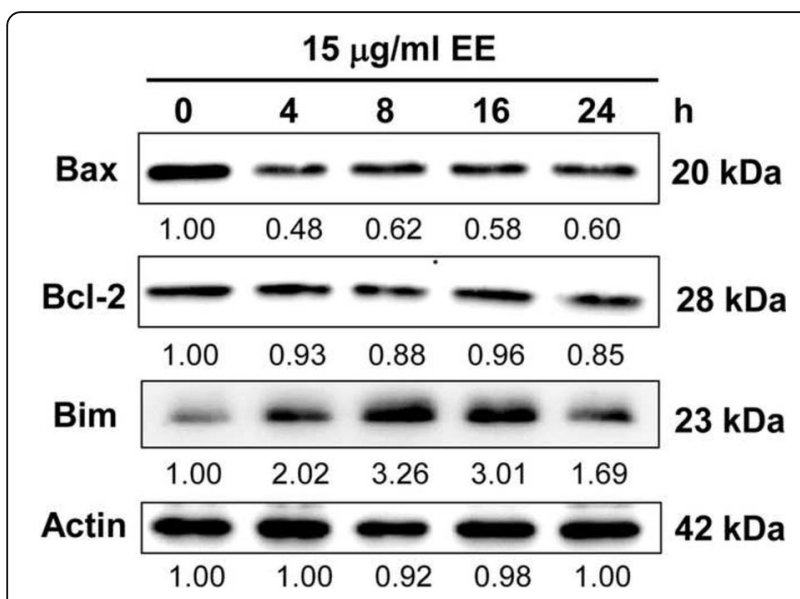

Fig. 5 Effect of EE extract on expression of $\mathrm{BCl}-2$ family proteins in $\mathrm{B} 16$ cells. Cells were treated with $15 \mathrm{\mu g} / \mathrm{ml}$ EE extract for $24 \mathrm{~h}$ and examined by Western blot analysis. Actin was used as the internal control

which associated with the regulation of cell survival or death. Extracellular signal-regulated kinase (ERK) promotes cell proliferation, differentiation and survival, whereas c-Jun N-terminal kinase (JNK) and p38 are known as stress-activated protein kinases. As shown in Fig. 7a, EE extract was able to decrease the level of phosphorylated and total ERK1/2 and p38 but unfortunately, both forms of JNK were undetectable.

AKT pathway is serine/threonine protein kinase that can promote cell survival, growth and proliferation. Phosphorylated Akt can inhibit the release of cytochrome c and apoptosis factor, thereby inhibiting apoptosis, and promote the growth of cancer cells. As seen in Fig. 7b, EE extract could decrease activity of total Akt and both forms of phosphorylated Akt after treatment for $4 \mathrm{~h}$. Therefore, EE extract inhibited cell survival of melanoma B16 cells via Akt suppression.

\section{Discussion}

It has been well known that dietary flavonoids, which commonly found in edible plants, have antioxidant effects, tumor cell growth inhibitory activity and apoptosis induction in cancer cell lines [15]. These could be served as chemopreventive agents. At present there are different forms of chemotherapy with several molecular targets but it is generally believed that chemotherapeutic agents kill cancer cells by induction of programmed cell death or apoptosis characterized morphologically by cell shrinkage, chromatin condensation and fragmentation and forming apoptotic bodies [16]. In this study, the results show EE extract, which composed of flavonoids, did not induce cytotoxic in normal Vero cells but could decrease cell survival of mouse melanoma B16 cells and also induce nuclear condensation. Remarkably, nuclear DNA fragmentation and apoptotic bodies were not found. Nevertheless, our results showed EE extract could induce phosphatidylserine exposure and loss of mitochondrial membrane potential using JC-1 staining, which are early markers of early phase of apoptosis.

On the other hand, Iwashita et al. [17] reported that several flavonoids including kaempherol and quercetin could inhibit the proliferation of B16 cells but both compounds seemed to have little effect in term of causing cell death. However, other flavonoids; isoliquiritigenin and butein, showed nuclear DNA fragmentation and apoptosis induction via the increase of Bax and suppression of $\mathrm{Bcl}-2$ and $\mathrm{Bcl}-\mathrm{X}_{\mathrm{L}}$. Moreover, Zhang et al. [18] showed quercetin induced nuclear condensation and DNA fragmentation in a dose-dependent pattern in mouse melanoma B16 cells. The results also demonstrated quercetin led to loss of mitochondrial membrane potential and enhanced apoptosis by decreasing the expression of $\mathrm{Bcl}-2$ and increasing of activity of caspase-3.

Two principle apoptosis pathways are the extrinsic and the intrinsic pathways. Each requires specific triggering signals to begin molecular events cascade regulated by the activation of caspases and the Bcl-2 family proteins [19]. The extrinsic pathway is triggered by death receptor-ligand binding such as Fas receptor and Fas ligand, then associated with the activation of caspase-8. The intrinsic pathway is triggered by cellular stress that results in release of cytochrome c from mitochondria into the cytosol and activation of caspase-9. Finally, both pathways initiate the activation of caspase-3
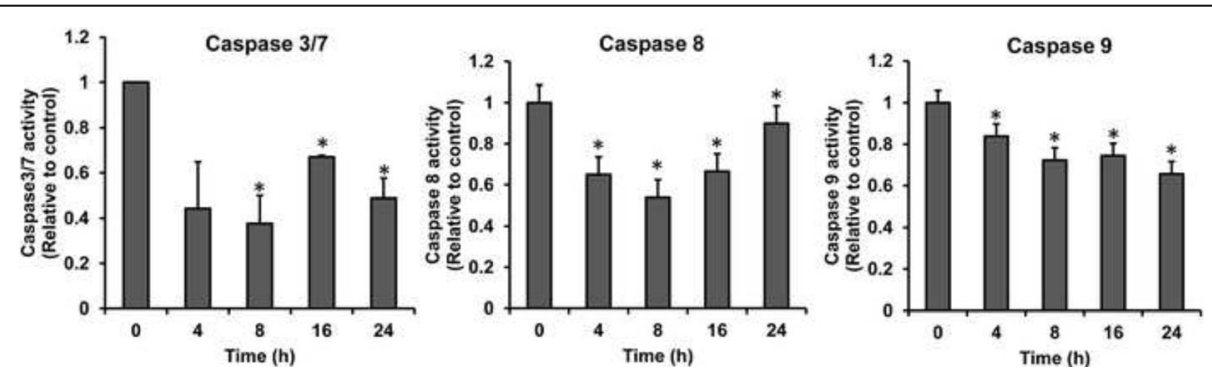

Fig. 6 Effect of EE extract on activity of caspase-3/7, -8, and - 9. B16 cells were treated with $15 \mu \mathrm{g} / \mathrm{ml}$ EE extract for $24 \mathrm{~h}$ and detected caspase activity using the Caspase-Glo ${ }^{\oplus}$ kits. Data were normalized to the caspase activity of control and are shown as mean values \pm SD of triplicate. ${ }^{*} p<0.05$ shows significant difference compared with control (0 h) 


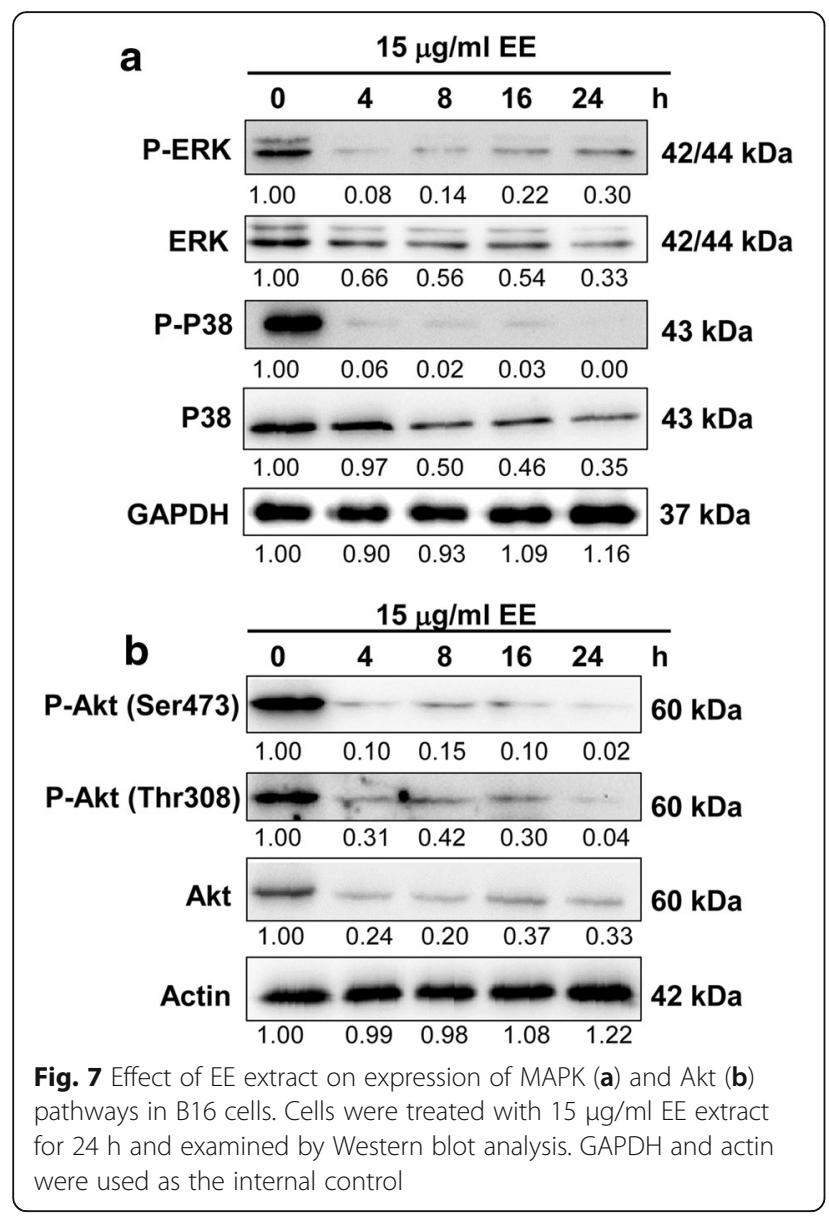

to induce cell death. The Bcl-2 family of proteins control mitochondrial membrane permeability and consist of pro-apoptotic such as Bax and Bak, and anti-apoptotic such as Bcl-2 and $\mathrm{Bcl}-\mathrm{X}_{\mathrm{L}}$ [20]. The third pro-apoptotic subgroup of $\mathrm{Bcl}-2$ family of proteins is $\mathrm{BH} 3$-only protein such as Bim and Bid. Our results showed the level of Bim was increase whereas no effect in the level of Bax and Bcl-2 after EE extract treatment in B16 cells. In addition, EE extract did not induce any activity of caspase-3, -8 , and -9 . It may suggest that EE extract could induce apoptosis via caspase-independent and Bim expression. Similarly, Wang et al. [21] demonstrated that inhibition of MEK/ERK pathway induced caspaseindependent apoptosis by the up-regulation of PUMA and Bim and down-regulation of Mcl-1 in human melanoma cells. Caspase-independent cell death pathway could be stimulated by factors released from mitochondria including apoptosis-inducing factor (AIF) and Endonuclease G (EndoG). Both factors translocate into nucleus and resulted in chromatin condensation and large scale $(50 \mathrm{~kb})$ DNA fragmentation [22]. The release of EndoG from mitochondria could be induced by BH3only protein such as tBid and Bim and could be inhibited by Bcl-2 [23].
The regulation of Bim by ERK1/2 and protein kinase B (PKB) or Akt pathways is downstream of oncogenic protein kinases [24]. Oncogenes could inhibit or neutralize Bim which facilitate tumor cell survival. The oncogenetargeted therapeutics caused down-regulation of ERK1/2 and/or PKB signaling and promoted increased expression of Bim to induce cell death in tumor cells become interestingly [25].

Previous study showed melanoma cells were resistant to apoptosis induction via activation of ERK1/2 [26]. The histological results of Zhuang et al. [27] revealed high level of activated ERK1/2 (p-ERK) in primary melanoma. Therefore, activation of ERK1/2 may be important in the development and progression of melanoma. Pre-clinical and clinical trial studies developed the treatment of melanoma by inhibition of this signaling pathway target including using BRAF inhibitors; the upstream of ERK1/2 [28, 29]. Inhibition of ERK pathway in melanoma cells with BRAF inhibitors results in cell cycle arrest and promotes cell death including apoptosis. Enhanced inhibition of ERK pathway by combination treatment such as BRAF and MEK inhibitors could induce more cell death and plus with the change in tumor microenvironment may affect to tumor progression [30]. In addition, BRAF ${ }^{\mathrm{V} 600 \mathrm{E}}$ inhibitor PLX4720 inhibited ERK1/2 and induced apoptosis via Bim splicing in melanoma cells [31].

Ordinarily, Akt signaling pathway regulates diverse cellular functions including cell growth, proliferation, survival, and migration in tumor cells. Quercetin also inhibits the activity of many kinases including protein tyrosine and serine/threonine kinases [32, 33]. Previous study showed quercetin enhanced UVB-induced cell death in B16 melanoma cells. It markedly attenuated MEK-ERK signaling and also disrupted phosphatidylinositol-3-kinase (PI3K)/ Akt survival signaling pathway [34]. This supported our results that EE extract down-regulated ERK and Akt signaling pathway in melanoma cells.

\section{Conclusion}

The first choice for treatment of early melanoma is surgery, whereas the treatment with chemotherapy remains unsatisfactory because most patients were diagnosed at the late stage and they lost surgical opportunity. This study proposed that EE extract has ability to decrease cell viability of B16 melanoma cells and induce apoptosis through caspase-independent associated with downregulation of ERK and Akt signaling pathways. This finding suggests that EE extract may be a chemopreventive or chemotherapeutic agent in skin cancer.

\section{Abbreviations}

Akt: the serine/threonine kinase or protein kinase B (PKB); Bak: BCl-2 homologous antagonist killer; Bax: BCl-2-associated death promoter; BCl-2: Bcell lymphoma 2; BCl- $\mathrm{X}_{\mathrm{L}}$ : B-cell lymphoma-extra large; $\mathrm{BH} 3$ : BCl-2 homology 
domain 3; Bid: BH3 interacting-domain death agonist; Bim: B-cell lymphoma interacting mediator of cell death; BRAF: v-raf murine sarcoma viral oncogene homologue B1; DMEM: Dulbecco's modified Eagle's medium; EE: Etlingera elatior; ERK: Extracellular signal-regulated kinase; FBS: Fetal bovine serum; h: hour; IC50: the half maximal inhibitory concentration; JC1: 5,5',6,6'-tetra- chloro-1,1',3,3'-tetraethylbenzimidazol-carbocyanine iodide; JNK: C-Jun N-terminal kinase; MAPK: mitogen-activated protein kinase; Mcl1: induced myeloid leukemia cell differentiation protein; min: minute; MTT: 3 (4,5-dimethylthiazol-2-yl)-2,5- diphenyl-2H-tetrazolium bromide; nm: nanometer; PUMA: p53 upregulated modulator of apoptosis

\section{Acknowledgements}

The authors gratefully acknowledge the financial support provided by Thammasat University under the TU New Research Scholar, Contact No. 14/ 2557. We also would like to thank Research Unit in Biological Activities of Bioactive compounds, Strategic Wisdom and Research Institute,

Srinakharinwirot University.

\section{Authors' contribution}

AK designed the research theme, performed experiments and drafted the manuscript. MC provided the EE extract. RW is the principal investigator, coordinated the project and approved the final manuscript

\section{Funding}

This study was supported by Thammasat University under the TU New Research Scholar, Contact No. 14/2557.

\section{Availability of data and materials}

The datasets during and/or analysed during the current study available from the corresponding author on reasonable request.

\section{Ethics approval and consent to participate}

Not applicable

\section{Consent for publication}

Not applicable

\section{Competing interests}

The authors declare that they have no competing interests.

\section{Publisher's Note}

Springer Nature remains neutral with regard to jurisdictional claims in published maps and institutional affiliations.

\section{Author details}

'Chulabhorn International College of Medicine, Thammasat University, Bangkok, Pathumthani, Thailand. 'Faculty of Pharmacy, Mahidol University, Bangkok, Thailand. '3epartment of Biochemistry, Faculty of Medicine, Srinakharinwirot University, Bangkok, Thailand.

\section{Received: 28 February 2017 Accepted: 11 August 2017}

\section{Published online: 22 August 2017}

\section{References}

1. Scherer D, Kumar R. Genetics of pigmentation in skin cancer-a review. Mutat Res. 2010;705:141-53.

2. Bhatia S, Tykodi S, Thompson A. Treatment of metastatic melanoma: an overview. Oncology (Williston Park). 2009;23(6):488-96.

3. Yin SY, Wei WC, Jian FY, Yang NS. Therapeutic applications of herbal medicines for cancer patients. Evid Based Complement Alternat Med 2013; 2013:302426. doi:https://doi.org/10.1155/2013/302426.

4. Ibrahim H. Kaempferia. In: de Padua LS, Bunyapraphatsara N, Lemmens RHMJ, editors. Plant resources of South-East Asia, Netherlands: Backhuys Publisher, vol. 12; 1999. p. 331-5.

5. Ibrahim H, Setyowati FM. Etlingera. In: de Guzman CC, Siemonsma JS, editors. Plant resources of South-East Asia, Pudoc, Wageningen, vol. 13; 1999. p. 123-6.

6. Chan EWC, Lim YY, Wong SK. Phytochemistry and pharmacological properties of Etlingera elatior: a review. Phcog J. 2011;3(22):1-6.
7. Maimulyanti A, Prihadi AR. Chemical composition, phytochemical and antioxidant activity from extract of Etlingera elatior flower from Indonesia. J Pharmacogn Phytochem. 2015;3(6):233-8.

8. Chan EWC, Lim YY, Wong LF, Lianto FS, Wong SK, Lim KK, et al. Antioxidant and tyrosinase inhibition properties of leaves and rhizomes of ginger species. Food Chem. 2008;109:477-83.

9. Chan EWC, Lim YY, Omar M. Antioxidant and antibacterial activity of leaves of Etlingera species (Zingiberaceae) in peninsular Malaysia. Food Chem. 2007:104:1586-93.

10. Punnawich Y, Montree I, Warin I, Kan C. Antifungal effects of Thai medicinal plants against Collectotrichum gloeosporioides Penz. Philip Agric Sci. 2009;92:265-70.

11. Mackeen MM, Ali AM, El-Sharkawy SH, Manap MY, Salleh KM, Lajis NH, et al. Antimicrobial and cytotoxic properties of some Malaysian traditional vegetables (ulam). Pharm Biol. 1997;35:174-8.

12. Habsah M, Ali AM, Lajis NH, Sukari MA, Yap YH, Kikuzaki H, et al. Antitumour promoting and cytotoxic constituents of Etlingera elatior. Malay J Med Sci. 2005;12:6-12.

13. Chan EWC, Lim YY, Ling SK, Tan SP, Lim KK, Khoo MGH. Caffeoylquinic acids from leaves of Etlingera species (Zingiberaceae). LWT-Food Sci Technol. 2009;42:1026-30.

14. Thuncharoen W, Chulasiri M, Nilwarangkoon S, Nakamura Y, Watanapokasin R. Apoptotic induction of skin cancer cell death by plant extracts. J Med Assoc Thail. 2013;96(Suppl 1):S60-4.

15. Kuo SM. Dietary flavonoids and cancer prevention: evidence and potential mechamisma. Crit Rev Oncog. 1997:8:47-69.

16. Soengas MS, Lowe SW. Apoptosis and melanoma chemoresistance. Oncogene. 2003;22:3138-51.

17. Iwashita K, Kobori M, Yamaki K, Tsushida T. Flavonoids inhibit cell growth and induce apoptosis in B16 melanma 4A5 cells. Biosci Biotechnol Biochem. 2000;64:1813-20.

18. Zhang X, Chen J, Xia Y, Xu Q. Apoptosis of murine melanoma B16-BL6 cells induced by quercetin targeting mitochondria, inhibiting expression of PKC$a$ and translocating PKC- $\delta$. Cancer Chemother Pharmacol 2005:55:251 262

19. Elmore S. Apoptosis: a review of programmed cell death. Toxicol Pathol. 2007;35(4):495-516.

20. Cory S, Adams JM. The BCl2 family: regulators of the cellular life-or-death switch. Nat Rev Cancer. 2002;2:647-56.

21. Wang YF, Jiang CC, Kiejda KA, Gillespie S, Zhang XD, Hersey P. Apoptosis induction in human melanoma cells by inhibition of MEK is caspaseindependent and mediated by the BCl-2 family members PUMA, Bim, and mcl-1. Clin Cancer Res. 2007;13(16):4934-42.

22. Cregan SP, Dawson VL, Slack RS. Role of AIF in caspase-dependent and caspase-independent cell death. Oncogene. 2004;23:2785-96.

23. Li LY, Luo X, Wang X. Endonuclease $G$ is an apoptotic DNase when release from mitochondria. Nature. 2001;412(6842):95-9.

24. Balmanno K, Cook SJ. Tumour cell survival signalling by the ERK1/2 pathway. Cell Death Differ. 2009:16:368-77.

25. Gillings AS, Balmanno K, Wiggins C, Johnson M, Cook SJ. Apoptosis and autophagy: BIM as a mediator of tumour cell death in response to oncogene-targeted therapeutics. FEBS J. 2009;276:6050-62.

26. Zhang XD, Borrow JM, Zhang XY, Nguyen T, Hersey P. Activation of ERK1/2 protects melanoma cells from TRAlL-induced apoptosis by inhibiting Smac/ DIABLO release from mitochondria. Oncogene. 2003:22:2869-81.

27. Zhuang L, Lee CS, Scolyer RA, McCarthy SW, Palmer AA, Zhang XD, et al. Activation of the extracellular signal regulated kinase (ERK) pathway in human melanoma. J Clin Pathol. 2005;58:1163-9.

28. Merat R, Seyde O, Fernandez E, Kaya G. Multiple palpebral syringomas occurring after initiation of BRAF inhibition therapy in a patient with metastatic melanoma. JAAD Case Reports. 2016;2:482-4.

29. Su F, Viros A, Milagre C, Trunzer K, Bollag G, Spleiss O, et al. RAS mutations in cutaneous squamous-cell carcinomas in patients treated with BRAF inhibitors. N Engl J Med. 2012;366:207-15.

30. McArthur GA. Combination therapies to inhibit the RAF/MEK/ERK pathway in melanoma: we are not done yet. Front Oncol. 2015:15:161.

31. Jiang CC, Lai F, Tay KH, Croft A, Rizos H, Becker TM, et al. Apoptosis of human melanoma cells induced inhibition of B-RAF ${ }^{\mathrm{V} 600 \mathrm{E}}$ involves preferential splicing of bim $_{\text {s. }}$ Cell Death Dis. 2010;1(9):e69.

32. Lou M, Zhang LN, Ji PG, Feng FQ, Liu JH, Yang C, et al. Quercetin nanoparticles induced autophagy and apoptosis through AKT/ERK/caspase3 signaling pathway in human neuroglioma cells: in vitro and in vivo. Biomed Pharmacother. 2016;84:1-9. 
33. Lou $X$, Sun B, Song J, Wang $Y$, Jaing J, Xu Y, et al. Human sulfatase 1 exerts anti-tumor activity by inhibiting the AKT/ CDK4 signaling pathway in melanoma. Oncotarget. 2016;7(51):84486-95.

34. Rafiq RA, Quadri A, Nazir LA, Peerzada K, Ganai BA, Tasduq SA. A potent inhibitor of phosphoinositide 3-kinase (PI3K) and mitogen activated protein (MAP) kinase Signalling, quercetin (3, 3', 4', 5, 7-Pentahydroxyflavone) promotes cell death in ultraviolet (UV)-B-irradiated B16F10 melanoma cells. PLoS One. 2015;10(7):e0131253.

Submit your next manuscript to BioMed Central and we will help you at every step:

- We accept pre-submission inquiries

- Our selector tool helps you to find the most relevant journal

- We provide round the clock customer support

- Convenient online submission

- Thorough peer review

- Inclusion in PubMed and all major indexing services

- Maximum visibility for your research

Submit your manuscript at www.biomedcentral.com/submit 